\title{
Sistem Pendukung Keputusan Menentukan Mekanik Terbaik Menggunakan Metode Simple Additive Weighting
}

\author{
Mahadika Bayu Pradipta ${ }^{1}$, Tutus Praningki ${ }^{2}$ \\ ${ }^{1}$ Teknik Informatika, Sekolah Tinggi Teknologi Cahaya Surya Kediri \\ ${ }^{2}$ Sekolah Tinggi Teknologi Cahaya Surya Kediri \\ E-mail: ${ }^{1}$ maha.pentta@gmail.com,2praningki@cahayasurya.ac.id
}

\begin{abstract}
ABSTRAK
Ahass Aries Sentosa Motor Kediri merupakan salah satu deler dan bengkel sepeda motor ternama di Kediri. Salah satu faktor kunci dalam mendapatkan predikat ternama dari konsumen adalah factor mutu mekanik khususnya dalam pelayanan servis sepeda motor di bengkel Ahass Aries Sentosa Motor Kediri. Pemanfaatan sistem pendukung keputusan sangat membantu dalam penentuan mekanik terbaik, dan disertai dengan metode Simple Additive Weighting (SAW), metode ini dapat menyelesaikan penelitian dengan mencari nilai bobot untuk setiap atribut, kemudian dilakukan proses perankingan yang akan menentukan alternatif yang optimal, yaitu mekanik yang berhak mendapat predikat sebagai mekanik terbaik. Dengan adanya sistem pendukung keputusan dengan metode Simple Additive Weighting (SAW) diterapkan pada permasalahan ini karena mampu menyeleksi alternatif terbaik dari sejumlah alternatif. Dalam hal ini akan lebih mempermudah memantau, menyeleksi dan menentukan mekanik yang berhak mendapat predikat sebagai mekanik terbaik.
\end{abstract}

Kata Kunci-Mekanik Terbaik, SAW, SPK. 


\begin{abstract}
Ahass Aries Sentosa Motor Kediri is one of the leading motorcycle dealers and workshops in Kediri. One of the key factors in getting a well-known predicate from consumers is the mechanical quality factor, especially in motorcycle service in the workshop Ahass Aries Sentosa Motor Kediri. The use of a decision support system is very helpful in determining the best mechanics, and is accompanied by the method of Simple Additive Weighting (SAW), this method can complete the research by looking for weight values for each attribute, then ranking process that will determine the optimal alternative, namely the entitled mechanics got the title as the best mechanic. With the decision support system with Simple Additive Weighting (SAW) method applied to this problem because it is able to select the best alternative from a number of alternatives. In this case it will be easier to monitor, select and determine the mechanics who are entitled to the title as the best mechanic.
\end{abstract}

Keywords-Best Mechanic, SAW, SPK. 


\section{PENDAHULUAN}

Persaingan bisnis di bidang pelayanan servis sepeda motor khususnya pada bengkel sepeda motor. Para pengusaha dituntut untuk memberikan pelayanan yang optimal kepada konsumennya. Seperti yang telah dilakukan oleh Ahass Aries Sentosa Motor Kediri yang terletak di Jl. Dhoho, No 40-42, Pakelan, Kec. Kota Kediri, Kota kediri, Jawa timur 64121. Dalam memberikan pelayanan servis yang maksimal kepada pelanggan. Manager menuntut para mekanisnya untuk bersaing secara sehat dan memicu semangat kinerja mekanik dengan cara memberikan bonus tiap bulan untuk mekanik yang berhasil mendapat predikat mekanik terbaik bulan ini.

Pemanfaatan sistem pendukung keputusan dengan menggunakan metode SAW tepat jika diterapkan pada permasalahan ini. Metode ini dipilih karena mampu menyeleksi alternatif terbaik dari sejumlah alternatif, dalam hal ini alternatif yang dimaksudkan yaitu yang layak mendapat predikat mekanik terbaik berdasarkan kriteriakriteria yang ditentukan. Penelitian dilakukan dengan mencari nilai bobot untuk setiap atribut, kemudian dilakukan proses perankingan yang akan menentukan alternatif yang optimal. Dengan metode perangkingan diharapkan lebih tepat dan akurat karena sudah didasarkan pada kriteria dan bobot yang sudah ditetapkan sehingga dapat menentukan siapa yang lebih berhak mendapat penghargaan tersebut. Sebagai contoh 2 penilitian terdahulu Sistem Pendukung Keputusan Pemilihan Karyawan Terbaik Menggunakan Metode SAW Pada PT. Berkah Cahaya Muria Kudus [1], dan Sistem Pendukung Keputusan Penentuan Kelayakan Daerah Pertanian Menggunakan Metode Saw yang berhasil menerapkan metode Simple Additive Weighting (SAW) [2].Pada studi kasusnya hanya memakai 3 Alternatif. Oleh karena itu pada penelitian ini akan menerapkan metode SAW dengan memakai lebih dari 3 alternatif Pada Ahass Aries Sentosa Motor Kediri untuk menentukan mekanik terbaik, tetapi timbul suatu permasalahan seperti yang tercantum dibawah ini. Dengan metode perangkingan diharapkan lebih tepat dan akurat karena sudah didasarkan pada kriteria dan bobot yang sudah ditetapkan sehingga dapat menentukan siapa yang lebih berhak mendapat penghargaan tersebut. 


\section{DASAR TEORI}

\subsection{Sistem Pendukung Keputusan}

Sistem pendukung keputusan merupakan sistem yang interaktif, membantu pengambilan keputusan melalui penggunaan data dan model-model keputusan untuk memecahkan masalah yang bersifat semi terstruktur dan tidak terstruktur. Menurut Maryam Alavi dan H. Albert Napier, sistem penunjang keputusan merupakan suatu kumpulan prosedur pemrosesan data dan informasi yang berorientasi pada penggunaan model untuk menghasilkan berbagai jawaban yang dapat membantu manajemen dalam pengambilan keputusan. Sedangkan menurut Litle, sistem penunjang keputusan merupakan suatu sistem informasi berbasis komputer yang menghasilkan berbagai alternatif keputusan untuk membantu manajemen dalam menangani berbagai permasalahan yang terstruktur ataupun tidak terstruktur dengan menggunakan data dan model.

\subsection{Metode SAW}

Konsep dasar metode Simple Additive Weighting adalah mencari penjumlahan terbobot dari rating kinerja pada setiap alternatif pada semua atribut (Fishburn, 1967) (MacCrimmon,1968). Metode ini membutuhkan proses normalisasi matriks keputusan ( ) kedalam skala yang dapat diperbandingkan dengan semua rating alternatif yang ada. Skor total untuk alternatif diperoleh dengan menjumlahkan seluruh hasil perkalian antara rating dan bobot tiap atribut.

Langkah penyelesaian metode SAW : (a) Menentukan kriteria yang akan dijadikan acuan dalam pengambilan keputusan, (b) Menentukan rating kecocokan setiap alternatif pada setiap kriteria, (c) Membuat matriks keputusan berdasarkan kriteria , (d) kemudian melakukan normalisasi matriks berdasarkan persamaan persamaan yang disesuaikan dengan jenis atribut (atribut keuntungan atau atribut biaya), (e) Membuat matriks normalisasi dan (f) Proses perankingan

\section{METODE PENELITIAN}

\subsection{Analisis Data}

\section{a. Pengumpulan Data.}

Data yang diperoleh langsung dari sumbernya, yaitu terdiri dari Observasi, Penulis mengumpulkan data yang dilakukan melalui pengamatan dan terjun langsung di Ahass Aries Sentosa Motor Kediri. Mencatat data mekanik dan kriteria-kriteria yang telah 
ditentukan oleh manager untuk mendukung pembuatan system, dan kriterianya ialah: Disiplin, Sikap kerja, Pelayanan, Service, Kreatifitas, Kerjasama.

Wawancara, dilakukan penulis kepada pihak Ahass Aries Sentosa Motor Kediri untuk memperoleh informasi bagaimana proses yang terjadi saat melakukan input data mekanik.

Dokumentasi adalah cara pengumpulan data adalah berdasarkan dokumendokumen yang ada di Ahass Aries Sentosa Motor Kediri yang berisi tentang informasi yang akan berhubungan dengan proses input data mekanik.

\section{b. Simple Additive Weighting (SAW)}

Metode Simple Additive Weighting (SAW) merupakan metode penjumlahan terbobot. Konsep dasar metode SAW adalah mencari penjumlahan terbobot dari rating kinerja pada setiap alternatif pada semua atribut [4]. Metode Simple Additive Weighting (SAW) membutuhkan proses normalisasi matriks keputusan $\mathrm{X}$ ke suatu skala yang dapat diperbandingkan dengan semua rating alternatif yang ada. Formula untuk melakukan normalisasi tersebut adalah sebagai berikut [3]:

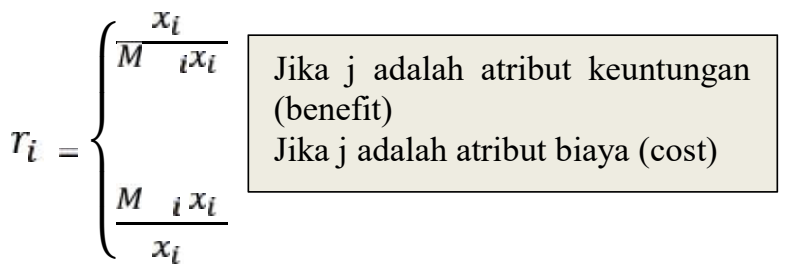

\section{Dimana :}

$r_{i} \quad=$ Rating kinerja ternormalisasi dari alternatif $\mathrm{Ai}(\mathrm{i}=, 2, \ldots, \mathrm{m})$

$M \quad{ }_{i}=$ Nilai maksimum dari setiap baris dan kolom.

$M_{i}=$ Nilai minimum dari setiap baris dan kolom.

$x_{i}=$ Baris dan kolom dari matriks.

$\left(r_{i}\right)$ adalah rating kinerja ternormalisasi dari alternatif $A_{i}$ pada atribut $C_{j} ; \mathrm{i}=1,2 \ldots, \mathrm{m}$ dan $\mathrm{j}=1,2 \ldots$... nilai preferensi untuk setiap alternatif $\left(V_{i}\right)$ diberikan sebagai berikut :

$$
V_{i}=\sum_{j=1}^{n} W_{j} r_{i}
$$


Formula untuk mencari nilai preferensi untuk setiap alternatif (Vi) diberikan sebagai berikut :

- $V_{i}=$ Nilai akhir dari alternatif

- $W_{i}=$ Bobot yang telah ditentukan

- $r_{i}=$ Normalisasi matriks.

- Nilai $V_{i}$ yang lebih besar mengindikasikan bahwa alternatif $A_{i}$ lebih terpilih

\subsection{Perancangan Sistem}

Pada perancangan sistem kali ini, penulis menggunakan alur program flowchart. Flowchartatau diagram alur adalah gambar simbol -simbol yang digunakan untuk menggambarkan urutan proses atau instruksi - intruksi yang terjadi di dalam suatu progam komputer secara sistematis dan logis. Berikut adalah simbol yang digunakan dalam pembuatan flowchart [5].

Tabel 1. Simbol - simbol Flowchart

\begin{tabular}{|l|l|}
\hline Simbol & \multicolumn{1}{|c|}{ Keterangan } \\
\hline & $\begin{array}{l}\text { Terminator } \\
\text { Sebagai simbol START atau END untuk } \\
\text { memulai ataupun mengakhiri flowchart }\end{array}$ \\
\hline & $\begin{array}{l}\text { Input atau output } \\
\text { Digunakan untuk menuliskan proses } \\
\text { menerima data atau mengeluarkan data. }\end{array}$ \\
\hline & $\begin{array}{l}\text { Proses } \\
\text { Digunakan untuk menuliskan proses yang } \\
\text { diperlukan }\end{array}$ \\
\hline & $\begin{array}{l}\text { Conditional / Decision } \\
\text { Digunakan untuk menyatakan proses yang } \\
\text { membutuhkan keputusan. }\end{array}$ \\
\hline & $\begin{array}{l}\text { Prepatation } \\
\text { Digunkan untuk memberikan nilai awal }\end{array}$ \\
\hline & $\begin{array}{l}\text { Arrow } \\
\text { Sebagai penunjuk arah dan alur proses }\end{array}$ \\
\hline &
\end{tabular}




\begin{tabular}{|l|l|}
\hline Simbol & $\begin{array}{l}\text { Connector (on-page) } \\
\text { Digunakan untuk menyatukan beberapa } \\
\text { arrow }\end{array}$ \\
\hline & $\begin{array}{l}\text { Keterangan } \\
\text { Digunkan untuk menghubungkan } \\
\text { flowchart yang harus digambarkan pada } \\
\text { halaman yang berbeda. }\end{array}$ \\
\hline & $\begin{array}{l}\text { Display, } \\
\text { Digunakan untuk menampilkan data ke } \\
\text { monitor }\end{array}$ \\
\hline
\end{tabular}

\section{HASIL DAN PEMBAHASAN}

\subsection{Flowchart}

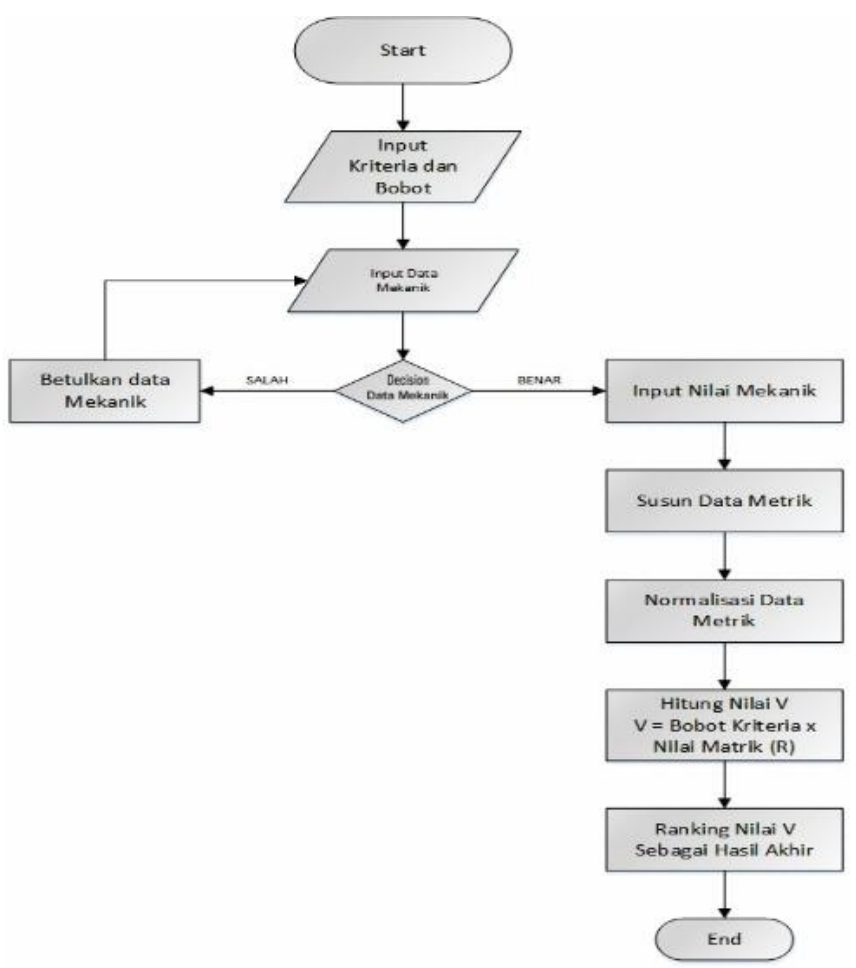

Gambar 1. Flowchat Sistem

Flowchart atau diagram alur adalah gambar simbol simbol yang digunakan untuk menggambarkan urutan proses atau instruksi-intruksi yang terjadi di dalam suatu progam komputer secara sistematis dan logis. 
Sistem di mulai dari start, setelah itu menginputkan data kriteria dan bobot kriteria, setelah itu menginputkan data mekanik. Setelah menginputkan data kriteria, bobot, dan mekanik setelah itu sistem menuju ke decision. Pada decision akan dilakukan proses, apabila data salah, data akan di kembalian pada input data mekanik untuk memperbaiki data hingga benar. Setelah data benar, selanjutnya data menuju ke proses input nilai mekanik, setalah itu menuju ke proses susun data matrik, setelah itu ke proses normalisasi data matrik, stelah itu menuju ke proses hitung nilai V. Setelah terhitug dan mendapat nilai V. Selanjutnya menuju ke proses ranking nilai V sebagai hasil akhir dan End proses selesai.

\subsection{Analisis Data}

Untuk menyelesaikan masalah dengan metode simple additive weighting(SAW).Langkah pertama adalah Menentukan alternatif, yaitu $\boldsymbol{A}_{\boldsymbol{i}}$. Sebagai contoh saya mengambil 8 alternatif sebagai berikut:

A1: Hari A5: Imam

A2: Adi $\quad$ A6: Ferdi

A3: Budi A7: Priya

A4: Aan A8: Puji

Menentukan kriteria-kriteria yang akan dijadikan acuan dalam pengambilan keputusan, yaitu Ci.. Kriteria yang dijadikan untuk pengolahan data pemilihan karyawan terbaik, yaitu:

Tabel 2. Tabel Kriteria

\begin{tabular}{|c|c|c|c|c|c|c|c|}
\hline Kriteria & Disiplin & $\begin{array}{c}\text { Sikap } \\
\text { Kerja }\end{array}$ & Pelayanan & Service & Kreatifitas & Kerjasama & Total \\
\hline Bobot & 15 & 30 & 15 & 20 & 10 & 10 & 100 \\
\hline
\end{tabular}

Tabel 3. Tabel Nilai Bobot (sub_kriteria)

\begin{tabular}{|l|c|l|}
\hline \multicolumn{3}{|c|}{ Tabel Nilai Bobot } \\
\hline Acuhan Nilai & Keterangan & Nilai \\
\hline$<=20-<=30$ & Sangat Rendah & 20 \\
\hline$>=40-<=50$ & Rendah & 40 \\
\hline$>=60-<=70$ & Cukup & 70 \\
\hline$>=80-<=90$ & Tinggi & 90 \\
\hline 100 & Sangat tinggi & 100 \\
\hline
\end{tabular}


Tabel nilai bobot ini hanya sebagai acuan dalam pengambilan keputusan nilai.Menentukan rating kecocokan setiap alternatif pada setiap kriteria. Membuat matriks keputusan berdasarkan kriteria(Ci), kemudian melakukan normalisasi matriks berdasarkan persamaan yang disesuaikan dengan jenis atribut sehingga diperoleh matriks ternormalisasi R. Matriks keputusan dibentuk dari tabel kecocokan sebagai berikut:

$\left(\begin{array}{llllll}90 & 70 & 70 & 40 & 90 & 40 \\ 70 & 70 & 90 & 70 & 70 & 90 \\ 40 & 90 & 70 & 70 & 40 & 70 \\ 90 & 70 & 40 & 40 & 70 & 70 \\ 90 & 40 & 40 & 70 & 90 & 40 \\ 70 & 90 & 70 & 40 & 40 & 70 \\ 40 & 70 & 70 & 40 & 70 & 90 \\ 70 & 40 & 40 & 90 & 40 & 70\end{array}\right)$

Normalisasi matriks $\mathrm{X}$ menggunakan persamaan 1

Alternatif : A2

Alternatif : A1

$$
\begin{aligned}
& r_{1}=\frac{90}{m \quad\{90,70,40,90,90,70,40,70\}} \\
& =\frac{90}{90}=1 \\
& r_{1}=\frac{70}{m \quad\{90,70,40,90,90,70,40,70\}} \\
& =\frac{70}{90}=0.777 \\
& r_{1}=\frac{70}{m \quad\{90,70,40,90,90,70,40,70\}} \\
& =\frac{70}{90}=0.777 \\
& r_{1}=\frac{40}{m \quad\{90,70,40,90,90,70,40,70\}} \\
& =\frac{40}{90}=0,444 \\
& r_{1}=\frac{90}{m \quad\{90,70,40,90,90,70,40,70\}} \\
& =\frac{90}{70}=1 \\
& r_{1}=\frac{40}{m \quad\{90,70,40,90,90,70,40,70\}} \\
& =\frac{40}{90}=0,444
\end{aligned}
$$

$$
\begin{array}{r}
r_{2}=\frac{70}{m} \quad \begin{array}{r}
\{90,70,40,90,90,70,40,70\} \\
=\frac{70}{90}=0,777
\end{array} \\
r_{2}=\frac{70}{m \quad\{90,70,40,90,90,70,40,70\}} \\
=\frac{70}{90}=0.777 \\
r_{2}=\frac{90}{m \quad\{90,70,40,90,90,70,40,70\}} \\
=\frac{90}{90}=1 \\
r_{2}=\frac{70}{m \quad\{90,70,40,90,90,70,40,70\}} \\
=\frac{70}{90}=0.777 \\
r_{2}=\frac{70}{m \quad\{90,70,40,90,90,70,40,70\}} \\
=\frac{70}{90}=0.777 \\
r_{2}=\frac{90}{m \quad\{90,70,40,90,90,70,40,70\}} \\
=\frac{90}{90}=1
\end{array}
$$


Alternatif : A3

$$
\begin{array}{rr}
r_{3}=\frac{40}{m} & \{90,70,40,90,90,70,40,70\} \\
& =\frac{40}{90}=0,444 \\
r_{3}=\frac{90}{m} & \{90,70,40,90,90,70,40,70\} \\
& =\frac{90}{90}=1
\end{array}
$$

Alternatif : A4

$$
\begin{aligned}
& r_{4}=\frac{90}{m \quad\{90,70,40,90,90,70,40,70\}} \\
& =\frac{90}{90}=1 \\
& r_{4}=\frac{70}{m \quad\{90,70,40,90,90,70,40,70\}} \\
& =\frac{70}{90}=0.777 \\
& r_{4}=\frac{40}{m \quad\{90,70,40,90,90,70,40,70\}} \\
& =\frac{40}{90}=0,444 \\
& r_{4}=\frac{40}{m \quad\{90,70,40,90,90,70,40,70\}} \\
& =\frac{40}{90}=0,444
\end{aligned}
$$

$$
\begin{aligned}
& r_{4}=\frac{70}{m \quad\{90,70,40,90,90,70,40,70\}} \\
& =\frac{70}{90}=0.777 \\
& r_{4}=\frac{70}{m \quad\{90,70,40,90,90,70,40,70\}} \\
& =\frac{70}{90}=0.777
\end{aligned}
$$

Alternatif : A5

$$
\begin{aligned}
& r_{5}=\frac{90}{m \quad\{90,70,40,90,90,70,40,70\}} \\
& =\frac{90}{90}=1 \\
& r_{5}=\frac{40}{m \quad\{90,70,40,90,90,70,40,70\}} \\
& =\frac{40}{90}=0,444 \\
& r_{5}=\frac{40}{m \quad\{90,70,40,90,90,70,40,70\}} \\
& =\frac{40}{90}=0,444 \\
& r_{5}=\frac{70}{m \quad\{90,70,40,90,90,70,40,70\}} \\
& =\frac{70}{90}=0.777 \\
& r_{5}=\frac{90}{m \quad\{90,70,40,90,90,70,40,70\}} \\
& =\frac{90}{90}=1 \\
& r_{5}=\frac{40}{m \quad\{90,70,40,90,90,70,40,70\}} \\
& =\frac{40}{90}=0,444
\end{aligned}
$$

Alternatif : A6

$$
\begin{array}{r}
r_{6}=\frac{70}{m} \quad \begin{array}{r}
\{90,70,40,90,90,70,40,70\} \\
=\frac{70}{90}=0.777 \\
90
\end{array} \\
r_{6}=\frac{90,90,90,70,40,70\}}{m \quad\{90,70,40,90}=1 \\
=\frac{90}{90}=10 \\
r_{6}=\frac{70}{m \quad\{90,70,40,90,90,70,40,70\}}=0.777 \\
=\frac{90}{90}
\end{array}
$$




$$
\begin{array}{r}
r_{6}=\frac{40}{m} \quad \begin{array}{r}
\{90,70,40,90,90,70,40,70\} \\
=\frac{40}{90}=0,444
\end{array} \\
r_{6}=\frac{40}{m \quad\{90,70,40,90,90,70,40,70\}} \\
=\frac{40}{90}=0,444 \\
r_{6}=\frac{70}{m \quad\{90,70,40,90,90,70,40,70\}} \\
=\frac{70}{90}=0.777
\end{array}
$$

Alternatif : A7

$$
\begin{array}{rr}
r_{7}=\frac{40}{m} & \{90,70,40,90,90,70,40,70\} \\
=\frac{40}{90}=0,444 & 70 \\
r_{7}=\frac{70}{m} \quad\{90,70,40,90,90,70,40,70\} \\
=\frac{70}{90}=0.777 \\
r_{7}=\frac{70}{m \quad\{90,70,40,90,90,70,40,70\}} \\
=\frac{70}{90}=0.777 \\
r_{7}=\frac{40}{m \quad\{90,70,40,90,90,70,40,70\}} \\
=\frac{40}{90}=0,444 \\
r_{7}=\frac{70}{m \quad\{90,70,40,90,90,70,40,70\}} \\
=\frac{70}{90}=0.777
\end{array}
$$

$$
\begin{gathered}
r_{7}=\frac{90}{m \quad\{90,70,40,90,90,70,40,70\}} \\
=\frac{90}{90}=1
\end{gathered}
$$

Alternatif : A8

$$
\begin{array}{rr}
r_{8}=\frac{70}{m} & \{90,70,40,90,90,70,40,70\} \\
=\frac{70}{90}=0.777 \\
r_{8}=\frac{40}{m} \quad\{90,70,40,90,90,70,40,70\} \\
=\frac{40}{90}=0,444 \\
r_{8}=\frac{40}{m} \quad\{90,70,40,90,90,70,40,70\}
\end{array}
$$$$
=\frac{40}{90}=0,444
$$$$
r_{8}=\frac{90}{m \quad\{90,70,40,90,90,70,40,70\}}
$$$$
=\frac{90}{90}=1
$$$$
r_{85}=\frac{40}{m \quad\{90,70,40,90,90,70,40,70\}}
$$$$
=\frac{40}{90}=0,444
$$$$
r_{8}=\frac{70}{m \quad\{90,70,40,90,90,70,40,70\}}
$$$$
=\frac{70}{90}=0.777
$$

Dari hasil perhitungan di atas maka didapat matriks ternomalisasi r sebagai berikut:

$\left(\begin{array}{ccccc}1 & 0,777 & 0,777 & 0,444 & 1 \\ 0,777 & 0,777 & 1 & 0,777 & 0,777 \\ 0,444 & 1 & 0,777 & 0,777 & 0,444 \\ 1 & 0,777 & 0,444 & 0,444 & 0,777 \\ 1 & 0,444 & 0,444 & 0,777 & 1 \\ 0,777 & 1 & 0,777 & 0,444 & 0,444 \\ 0,444 & 0,777 & 0,777 & 0,444 & 0,777 \\ 0,777 & 0,444 & 0,444 & 1 & 0,444\end{array}\right)$


Mencari alternatif terbaik menggunakan persamaan

Vektor bobot $\mathrm{W}=(15,30,15,20,10,10)$

$$
\begin{aligned}
\mathrm{V}_{1} & =(1 \times 15)+(0,777 \times 30)+(0,777 \times 15)+(0,444 \times 20)+(1 \times 10)+(0,444 \times 10) \\
& =73.33333333 \\
\mathrm{~V}_{2} & =(0,777 \times 15)+(0,777 \times 30)+(1 \times 15)+(0,777 \times 20)+(0,777 \times 10)+(1 \times 10) \\
& =83.33333333 \\
\mathrm{~V}_{3} & =(0,444 \times 15)+(1 \times 30)+(0,777 \times 15)+(0,777 \times 20)+(0,444 \times 10)+(0,777 \times 10) \\
& =76.1111111 \\
\mathrm{~V}_{4} & =(1 \times 15)+(0,777 \times 30)+(0,444 \times 15)+(0,444 \times 20)+(0,777 \times 10)+(0,777 \times 10) \\
& =69.44444444 \\
\mathrm{~V}_{5} & =(1 \times 15)+(0,444 \times 30)+(0,444 \times 15)+(0,777 \times 20)+(1 \times 10)+(0,444 \times 10) \\
& =65 \\
\mathrm{~V}_{6} & =(0,777 \times 15)+(1 \times 30)+(0,777 \times 15)+(0,444 \times 20)+(0,444 \times 10)+(0,777 \times 10) \\
& =74.44444444 \\
\mathrm{~V}_{7} & =(0,444 \times 15)+(0,777 \times 30)+(0,777 \times 15)+(0,444 \times 20)+(0,777 \times 10)+(1 \times 10) \\
& =68.33333333 \\
\mathrm{~V}_{8} & =(0,777 \times 15)+(0,444 \times 30)+(0,444 \times 15)+(1 \times 20)+(0,444 \times 10)+(0,777 \times 10) \\
& =63.88888889
\end{aligned}
$$

Nilai yang terbesar ada pada V2 sehingga alterntif A2 yaitu Adi yang terpilih sebagai alternatif terbaik. Dengan kata lain Adi yang berhak mendapat predikat mekanik terbaik.

\subsection{Interface Sistem}

\section{a. Interface Data Alternatif}

Form ini berfungsi sebagai form input data alternatif yang bisa mengakses menu alternatif. Di dalamnya berisakan inputan data alternatif, rangkuman data alternatif.

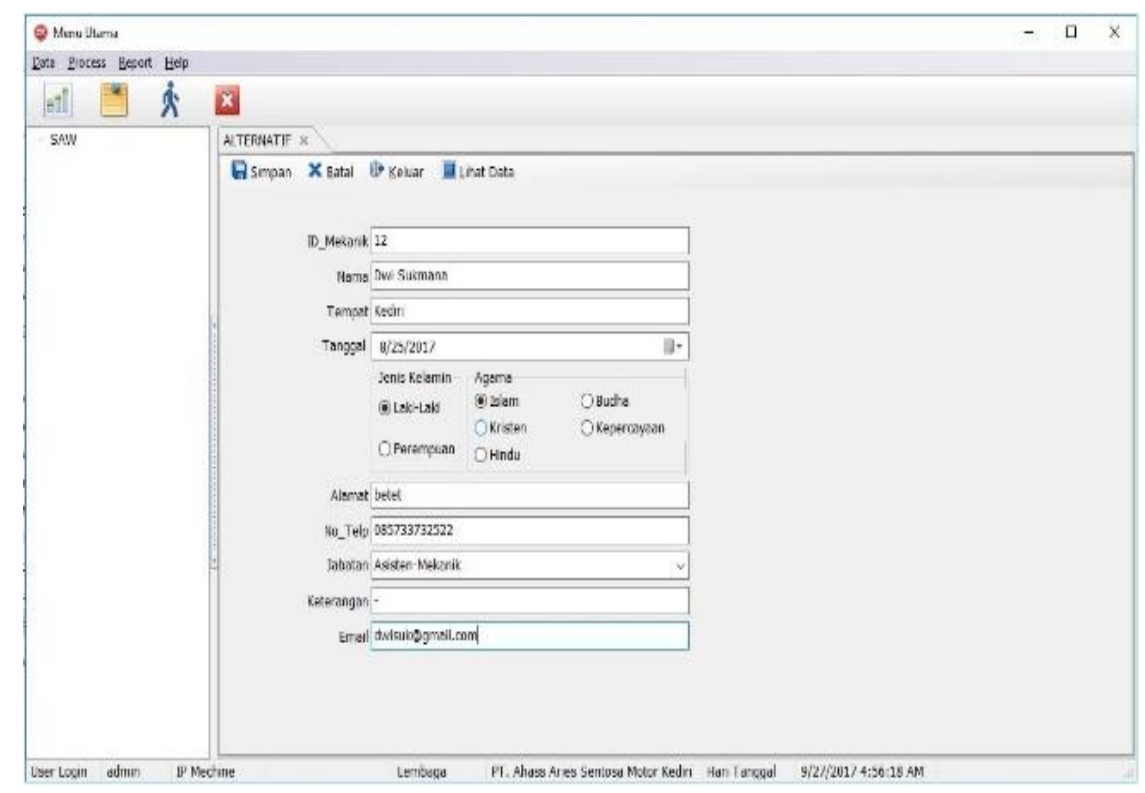

Gambar 2. Form Data alternatif 


\section{b. InterfaceData Kriteria Master}

Form ini berfungsi sebagai form input data kriteria master yang bisa mengakses menu kriteria master. Di dalamnya berisakan inputan data kriteria master rangkuman data kriteria master.

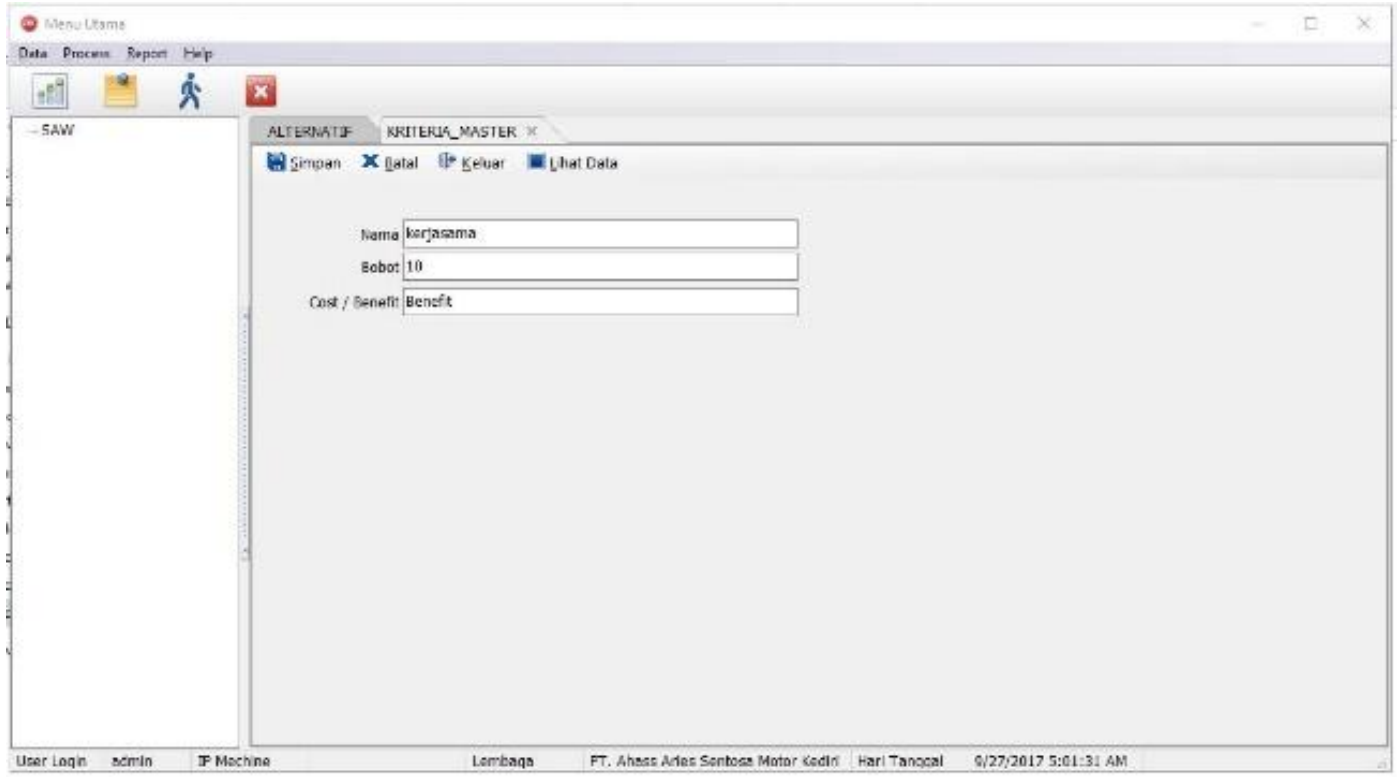

Gambar 3. Form Data Kriteria Master

\section{c. Interface Data Kriteria Detail}

Form ini berfungsi sebagai form input data kriteria detail yang bisa mengakses menu kriteria detail. Di dalamnya berisakan inputan data kriteria detail, rangkuman data kriteria detail.

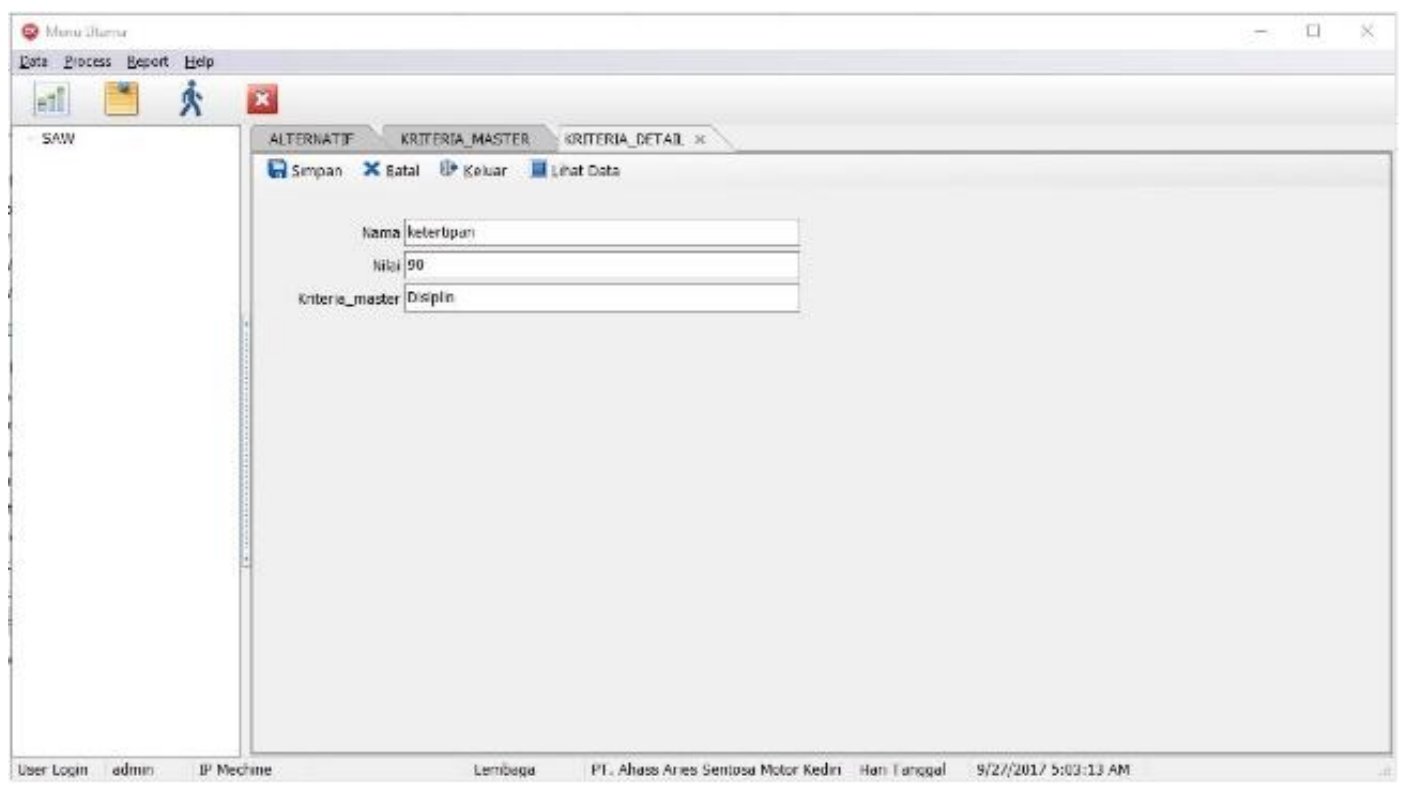

Gambar 4. Form Data Kriteria detail 


\section{d. InterfaceProsesRating}

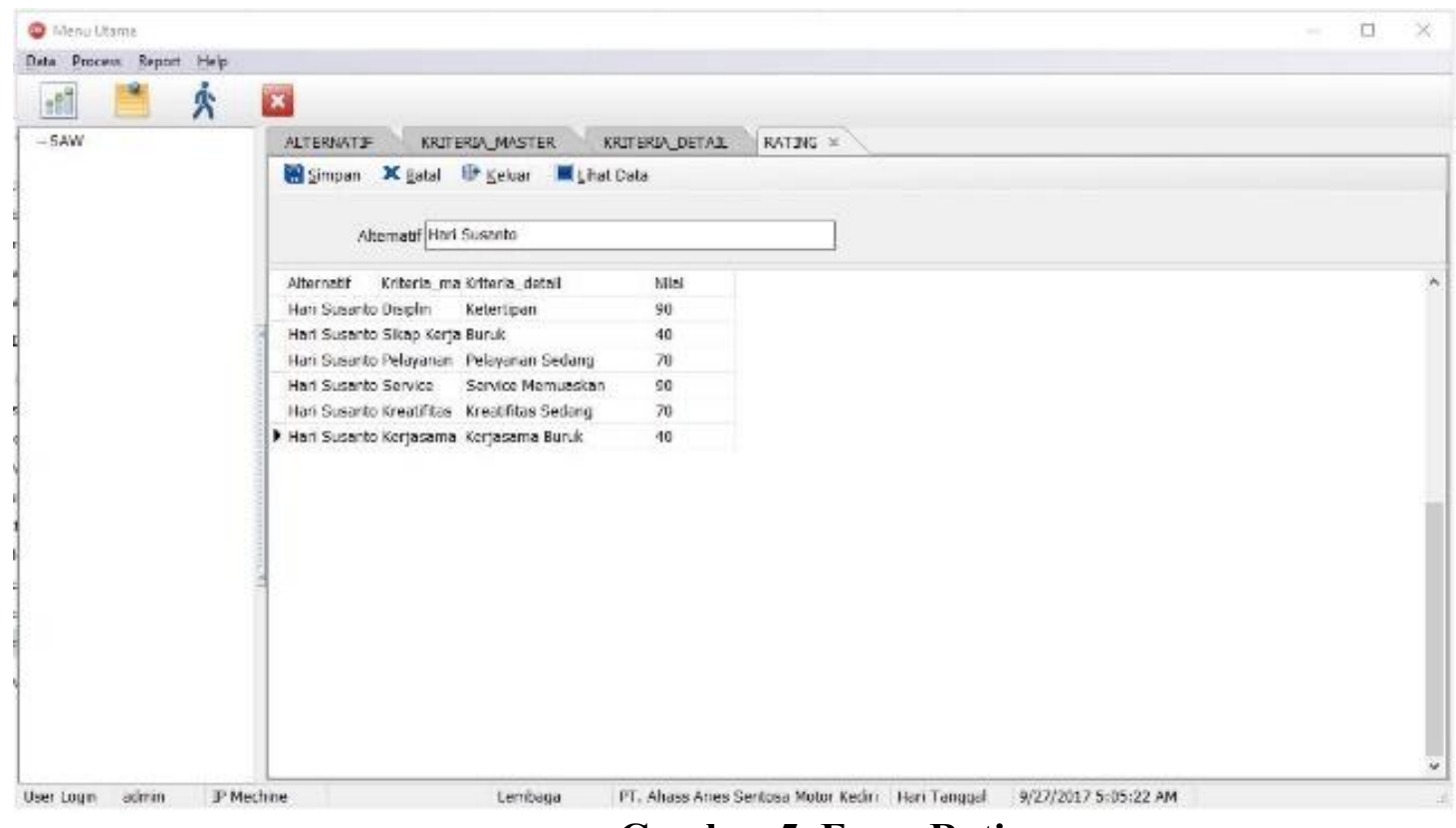

\section{Gambar 5. Form Rating}

Form ini berfungsi sebagai form input dan proses nilai. Pertama harus menginputkan data Alternatif dan data kriteria. Semua data yang di ambil bisa di lihat pada form input sebelumnya.

\section{e. InterfaceNilai Ranking}

Form ini berfungsi sebagai form report nilai ranking. Tempat mengolah dan output nilai ranking.

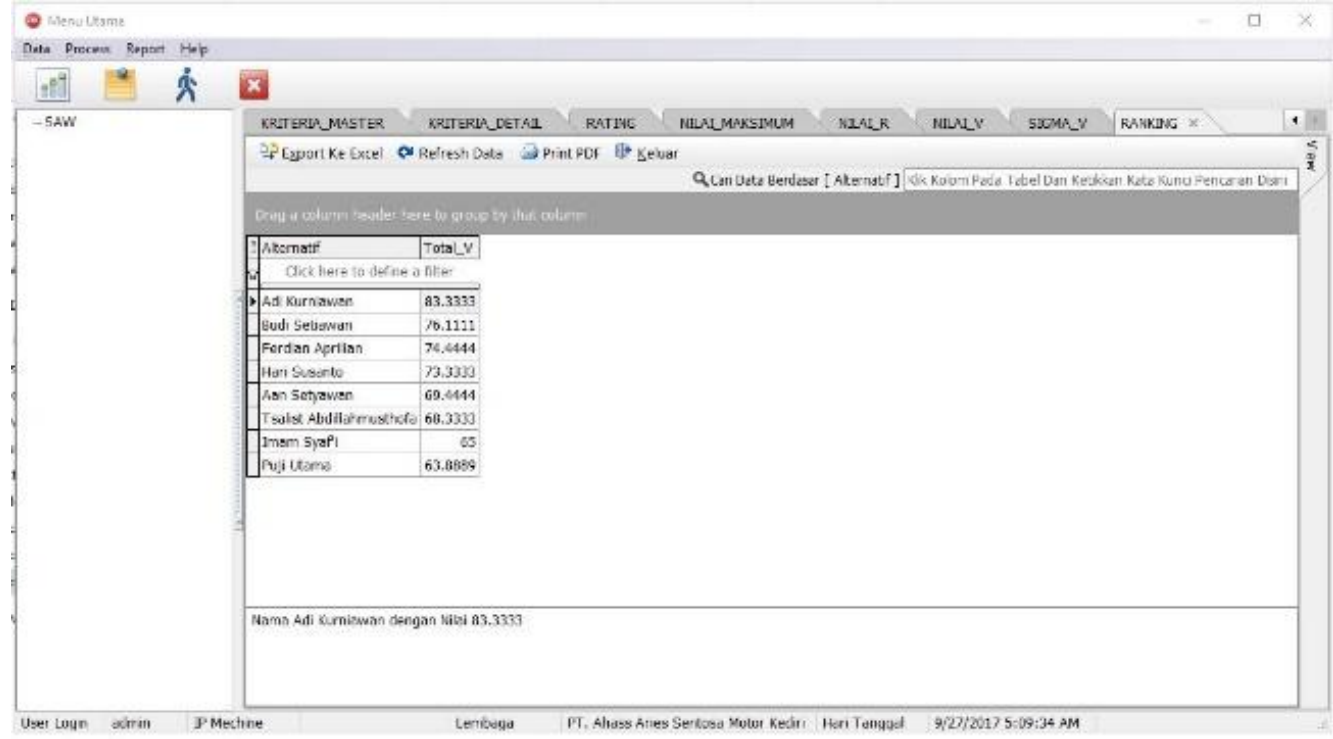

Gambar 6. Form Report Nilai Ranking 


\section{PENUTUP}

\subsection{Kesimpulan}

Hasil implementasi, analisa, pengujian serta pembahasan dari hasil penelitian pada aplikasiSistem Pendukung Keputusan Menentukan Mekanik Terbaik Pada Ahass Aries Sentosa Motor Kediri Menggunakan Metode Simple Additive Weighting(SAW).Maka dapat diambil kesimpulan sebagai berikut :

a. Metode Simple Additive Weighting (SAW) dapat diterapkan dan lebih efisien dalam mencari alternatifmekanik terbaik pada ahass aries sentosa motor kediri.

b. Penerapan sistem pendukung keputusan dengan metode simple additive weighting ini dilakukan berdasarkan hasil dari perangkingan mulai dari alternatif terbesar sampai terkecil. Hasil dari proses sistem pendukung keputusan penentuan mekanik terbaik ini dapat digunakan sebagai bahan pertimbangan untuk menentukan mekanik yang mendapat predikat karyawan terbaik bulan ini.

c. Penyelesaian kriteria-kriteria dilakukan dengan menghitung bobot nilai dari setiap kriteria yaitu, disiplin, sikap kerja, pelayanan, service, kreatifitas, kerjasama.

d. Aplikasi sistem pendukung keputusan dirancang berdasarkan penentuan kriteria dan perhitungan yang telah diperoleh, dan menggunakan perancangan berupa use case dan activity diagram.

\subsection{Saran}

Setelah selesai melalui beberapa tahapan mulai dari perancangan, penerapan sistem, implementasi dan pengujian, ada beberapa hal yang perlu diperhatikan dalam menggunakan program aplikasi menentukan mekanik terbaik ini, antara lain :

a. Perlu dilakukan pemeliharaan dan pengawasan dari pihak yang bertanggung jawab terhadap sistem.

b. Memilih seorang Administrator yang terlatih, jujur, dan bertanggung jawab baik dalam penggunaan maupun pemeliharaan program aplikasi.

c. Terintegrasi dengan sistem informasi lain yang ada di ahass aries sentosa motor kediri sehingga akan mempermudah admin dalam menggunakannya.

Sistem ini tentunya masih banyak kekurangan serta kelemahan di dalamnya, oleh karena itu perlu dikembangkan lagi agar menjadi sistem yang jauh lebih baik lagi kedepannya. Diharapkan nanti ada pengguna yang dapat mengembangkan sistem ini 
maupun menggunakan metode Simple Additive Weighting (SAW) atau dengan metode metode lainnya.

\section{DAFTAR PUSTAKA}

[1] Denay Islam Sabanayo, 2016,"Sistem Pendukung Keputusan Pemilihan Karyawan Terbaik Menggunakan Metode SAW Pada PT. Berkah Cahaya Muria Kudus". Program Studi Teknik Informatika, Universitas Dian Nuswantor Semarang.

[2] Elvina Lubis,2013,"Sistem Pendukung Keputusan Penentuan Kelayakan Daerah Pertanian Menggunakan Metode SAW". Program Studi Teknik Informatika STMIK Budi Darma Medan.

[3] Kusumadewi, S., Hartati, S., Harjoko A., Wardoyo R., 2006, Fuzzy Multi-Attribute Decision Making (Fuzzy MADM), Graha Ilmu, Yogyakarta.

[4] Pahlevy, Randy, Tesar. 2010. Rancang Bangun Sistem pendukung Keputusan Menentukan penerima Beasiswa dengan Menggunakan metode Simpele Additive Weighting (SAW). Skripsi Program Studi Tehnik Informatika. Surabaya: Universitas Pembangunan Nasional "Veteran".

[5] Jugianto. 2005. Analisis dan Desain Sistem Informasi : Pendekatan Terstruktur Teori dan Praktek Aplikasi Bisnis, Andi, Yogyakarta.

[6] Fishburn, P. C., 1967. A Problem-based selection of multi-attribute decision making methods, Blackwell Publishing.

[7]MacCrimmon, K. R. 1968. Decision Making among multiple atribute alternatives: a survey and consolidated approach.

[8] S. W. Mudjanarko, S. Winardi, and A. D. Limantara, "Pemanfaatan internet of things (iot) sebagai solusi manejemen transportasi kendaraan sepeda motor," Pros. Semin. Nas. Apl. Teknol. Prasarana Wil. X, no. August, 2017, doi: 10.17605/OSF.IO/6UE4B.

[9] A. D. Triono et al., "Utilization of Pedestrian Movement on the Sidewalk as a Source of Electric Power for Lighting Using Piezoelectric Censors," in 2018 3rd IEEE International Conference on Intelligent Transportation Engineering, ICITE 2018, 2018, doi: 10.1109/ICITE.2018.8492624.

[10] A. D. Limantara, L. D. Krisnawati, S. Winardi, and S. W. Mudjanarko, "Solusi Pengawasan Kebijakan Mengatasi Kemacetan Jalan dan Parkir Kota Berbasis Internet Cerdas," Semin. Nas. Teknol. dan Rekayasa Inf., no. November, pp. 1-6, 2017.

[11] A. D. Limantara, S. Winarto, and S. W. Mudjanarko, "Sistem Pakar Pemilihan Model Perbaikan Perkerasan Lentur berdasarkan Indeks Kondisi Perkerasan 
(Pci)," Semin. Nas. dan Teknol. Fak. Tek. Universtas Muhammadiyah Surakarta, no. November, pp. 1-2, 2017, [Online]. Available: https://jurnal.umj.ac.id/index.php/semnastek/article/view/1807.

[12] A. D. Limantara, Y. C. S. Purnomo, and S. W. Mudjanarko, "Pemodelan Sistem Pelacakan LOT Parkir Kosong Berbasis Sensor Ultrasonic Dan Internet Of Things ( IOT ) Pada Lahan Parkir Diluar Jalan," Semin. Nas. Sains dan Teknol., vol. 1, no. 2, pp. 1-10, 2017.

[13] A. D. Limantara et al., "Optimization of standard mix design of porous paving coconut fiber and shell for the parking area," in AIP Conference Proceedings, 2018, vol. 2020, doi: 10.1063/1.5062655.

[14] A. D. Limantara, A. Widodo, S. Winarto, L. D. Krisnawati, and S. W. Mudjanarko, "Optimizing the use of natural gravel Brantas river as normal concrete mixed with quality fc $=19.3 \mathrm{Mpa}$," in IOP Conference Series: Earth and Environmental Science, 2018, vol. 140, no. 1, doi: 10.1088/17551315/140/1/012104.

[15] S. Wiwoho Mudjanarko et al., "The Concrete Quality Testing for Trapezoidal Model of the Prefabricated Foundation," Int. J. Eng. Technol., vol. 7, no. January, pp. 311-315, 2018, doi: 10.14419/ijet.v7i3.25.17588.

[16] D. A. Yulmida, S. W. Mudjanarko, M. I. Setiawan, and A. D. Limantara, “Analisis Kinerja Parkir Sepanjang Jalan Walikota Mustajab," U KaRsT, vol. Volume1, no. nomor1, pp. 39-46, 2017, doi: http://dx.doi.org/10.30737/u\%20karst.v1i1.81.

[17] A. D. Limantara, E. Gardjito, A. Ridwan, E. Sustiyatik, P. Pudijohartomo, and H. L. Sudarmanto, "The Effect of Bioconc Against Compressive Strength of Paving Concrete Combining Natural Materials," vol. 7, no. x, pp. 89-91, 2018.

[18] A. D. Limantara and S. W. Mudjanarko, "Investigasi Forensik Kerusakan Perkerasan Lentur Jalan Raya,” UKaRsT, vol. 1, no. 1, pp. 85-105, 2017.

[19] E. Gardjito, A. D. Limantara, B. Subiyanto, and S. W. Mudjanarko, "Role of Project Related Parties on Quality Control (Concrete Structure) and Achievement of Project Performance," U KaRsT, vol. 2, no. 1, pp. 81-100, 2018.

[20] A. D. Limantara, E. Gardjito, B. Subiyanto, and S. W. Mudjanarko, "Modeling Decision Support to Prioritize Pavement Maintenance Activities in Indonesia," UKaRsT, vol. 2, no. 1, pp. 41-60, 2018.

[21] S. W. Mudjanarko, A. D. Limantara, B. Subiyanto, and F. Nurzandah, "Optimization of Standard Mix Design of Porous Paving Coconut Fiber for Parking Area," UKaRsT, vol. 2, no. 1, pp. 61-80, 2018. 
[22] D. A. Restuti, L. Rifani, A. D. Limantara, and B. Subiyanto, "APLIKASI WEB MIX DESAIN BETON BERDASARKAN METODE DOE (SNI 03-28472002)," U KaRsT, vol. 1, no. 2, pp. 36-50, 2017.

[23] E. Gardjito, A. D. Limantara, B. Subiyanto, and S. W. Mudjanarko, "PENGENDALIAN MUTU BETON DENGAN METODE CONTROL CHART (SPC) DAN PROCESS CAPABILITY (SIX-SIGMA) PADA PEKERJAAN KONSTRUKSI," U KaRsT, vol. 1, no. 2, pp. 80-105, 2017.

[24] N. Damastuti, R. D. Nasihien, A. D. Limantara, and B. Subiyanto, "COMPUTATIONAL FLUID DYNAMICS (CFD) UNTUK SIMULASI ALIRAN FLUIDA PADA BANGUNAN MASJID UNIVERSITAS NAROTAMA," U KaRsT, vol. 1, no. 2, 2017.

[25] A. Situmorang, A. D. Limantara, B. Subiyanto, and S. W. Mudjanarko, "PENINGKATAN DAYA DUKUNG TANAH DASAR LEMPUNG EKSPANSIF DENGAN STABILISASI KAPUR DAN GARAM," $U$ KaRsT, vol. 1, no. 2, pp. 68-79, 2017.

[26] W. ARGANATA, A. D. LIMANTARA, AND Y. CAHYO, "ANALISIS PERENCANAAN OVERLAY PADA RUAS JALAN CRAKENNGULUNGKULON NAMBAK-NGULUNGKULON DENGAN BAHAN ACL MENGGUNAKAN METODE BINA," J. MANAJ. TEKNOL. TEK. SIPIL, VOL. 2, NO. 1, PP. 121-131, 2017. 